\title{
Applying Songs for Listening Compre hension and Learning Motivation in Preparing National Examination at MA Maarif 06 Pasir Sakti
}

\author{
Eka Pra Setiyawati \\ Madrasah Aliyah Ma’arif 06 Pasir Sakti Lampung Timur \\ eprasetiyawati@gmail.com
}

Abstract

\begin{abstract}
This research discusses about the effectiveness of song towards the students' listening comprehension and their learning motivation for National Examination preparation in secondary school. The teacher applied the particular songs at beginning of listening class to attract and increase the students' listening ability. This research was Classroom Action Research and the data was taken with tests and questionnaires. The subject of the research was 28 students of grade twelve (Science class) who are going to do National Examination. The teacher targetted $75 \%$ of students exceed 20 score or more from maximum score 30 in listening section. The result showed that the students' listening comprehension was increased significantly. It could be seen from preliminary cycle was $11 \%$, in cycle 1 was $60 \%$, and in cycle 2 was $75 \%$ of students got the minimum score of 20 . The students' learning motivation was also improved as their listening achievement. Therefore, the teacher believed that a song can improve the students' listening comprehension and their learning motivation.
\end{abstract}

Key words : Song, Listening Comprehension, Learning Motivation

\section{INTRODUCTION}

English is one of the necessary course taught in secondary schools in Indonesia.Government has decided that English becomes one of the course tested in National Examination for students of secondary school. It aims to obtain the better life skills in English for facing globalization era.

In MA Ma'arif 06 Pasir Sakti, English is normally taught 8 hours a week during two semesters in every grade. In grade twelve, the students are specially given extra class for some courses of National Examination after the normal class in the morning. They are prepared to master the courses of National Examination well and graduate with good scores.It is also pointed for English as one of the course tested in National Examination.

There are some different types of questions in English course for National Examination. English consists of 50 questions which are divided into two skills, they are Listening and Reading. In listening section, there are four parts of questions ; Short Dialogue, Question and Response, Picture, and Monologue.

In daily classroom, the teacher instructed the listening with conventional media and technique. But, in fact the students admitted that they have many difficulties in Listening section. They couldn't comprehend well the speaker's taks in audio record although it was 
clear. Their low comprehension made the students were confused in filling the answers in Listening questions. It was proved with their listening achievement in every test given. Another hand, their low comprehension of listening was caused by their mastery of vocabularies. Definitely, their National Examination might not be prepared well. Richard (2008) states that Listening as comprehension is the traditional way of thinking about the natureof listening. Indeed, in most methodology manuals listening and listening comprehensionare synonymous. This view of listening is based on the assumptionthat the main function of listening in second language learning is to facilitateunderstanding of spoken discourse.Hence, Purcell (1992) also states that students can become bored by repeatedly listening to a narration or dialog as they attempt to understand the meaning of new words or phrases in context. Therefore, to cover that problems, the teacher who is a researcher in this study tries to use an interesting media in Listening class.

The teacher tends to apply song to solve thestudents' listening comprehension. It is regarded as the exact media to stimulate the students' listening skill. A music has the power to engrave itself into our brains, stating that "songs work on our short- and long-term memory" and are therefore adequate tools for using in the language classroom (Murphey (1992) cited in Millington (2011:135).

Millington (2011:135) states that songs can provide the opportunity for vocabulary practice. They are usually based around a theme or topic that can provide the context for vocabulary learning.He also adds that most children enjoy singing and usually respond well tousing songs in the classroom, but there are more significant benefits to using songs other than just being fun. First, songs can bring variety to the everyday classroom routine. This variety stimulates interest and attention, which can help maintain classroom motivation, thereby helping learners to reach higher levels of achievement. Secondly, songs, in particular choral singing, can help to create a relaxed and informal atmosphere that makes the classroom a nonthreatening environment. As mentioned in Brown (2006), anothertheme will be motivation. Because listening is so challenging, teachers need to think carefullyabout making the activities successful and the content interesting. We can create interesting andmotivating activities when listening such as using English songs. Thus, the students will bestimulated and not be frightened or worried when they are practicing lis tening.

There are two previous studies related to this study. First, Sung Kim and Koo Kang (2015) studied the effects of developing english listening ability ofmiddle school students through english pop songs. They say that for teaching and learning English listening skills, English pop songs can be used as an effective way and useful pattern practices related to the 
songs can be very helpful. English pop songs can help students feel more confident and enjoy English to learn more at home as well as in the classroom. The results of this study are English pop songs increased the students' interest and motivation for learning English, which were turned out to help the students get about three times more scores.

Second, Arevalo (2010) studied the use of songs as a tool to work on listening and culture in EFL classes. His findings of study indicate that the type of material can foster listening skills and engage students in discussion about cultural and social issues. He claims that his study results that practicing listening with songs can become a good way to train students in the development of higher levels of comprehension.

This study also implemented the song for increasing the students' listening comprehension which was different from the previous studies above in term of kind of songs, setting, and teaching steps. The teacher used the song because it fits with the students' needs and the problems happened in the listening class. Therefore, the teacher was interested in conducting classroom action research using song to increase the students' listening comprehension for National Examination preparation in grade twelve MA Ma' arif 06 Pasir Sakti.

\section{METHODOLOGY}

The research design of this inquiry is Classroom Action Research (CAR) because the teacher who is researcher also involves to do a process of planning, implementing, observing and reflecting. (Kemmis and Kagart, 1998). Further, the researcher prefers to use subject, object and focus instead of participants because this research is Classroom Action Research (CAR) as proposed by Kemmis and Kagart (1998).

The subject of the research was the students of grade XII of MA Maarif 6 Pasir Sakti East Lampung who are going to face National Examination. They are 28 students; 9 male and 19 female students. The object of this research was the students' achievement in listening comprehension and their responds towards the exposed media. The focus; The students whohave difficulties in comprehending the content of listening in the record, in understanding the vocabularies in conversations , and differing the answer in the options. Regarding on that problems, the implementation of song in listening class was needed.

In carrying out the research, the teacher does some following steps ; doing preliminary study, identifying problems, planning, implementing, observing and reflecting.

In pre-liminary study, the teacher gained the data from the students' achievement in listening daily class. From that data, the teacher observed some problems happened in the 
class. She found the students' listening comprehension is bad due to low vocabulary mastery, and they have less motivation in listening class. Those problems derived from the unsupported media of listening used by the teacher in the class.

Furthermore, in planning, the teacher outlined some things about questionnaire, media, teaching procedure, and criteria of success. First, she paraphased some statements into questionnaire about the students' learning motivation in listening class. It contained 20 statements (12 positive and 8 negative statements) which divided into 4 criteria of learning attitude (Excellent, good, enough, and poor). It aimed to know the students' learning motivation and their respond towards the media of listening. Second, in this research, the teacher used song as media of listening. Before it was applied to the classroom, the teacher sorted the level of song from the easiest until the hardest ones. The song are going to play as stimulation before answering the listening questions of National Examination. The students will be asked about the vocabularies they listened from the song and their comprehension about the content of the song. Third, in teaching procedure, the teacher designed the lesson plan during the listening class which will use song as media. The last, the teacher determined the criteria of success based on the scoring rubric of National Examination. Regarding that the total of listening questions in National Examination script is 15 out of 50 questions, so the teacher targetted $75 \%$ of students exceed 20 score or more .

In implementing, the teacher conducted the teaching and learning as designed in lesson plan. At the beginning, the teacher used brainstorming with song, then the students' were asked to listen the song for three times. After that, the teacher questioned the vocabularies included to the song and their comprehension about the content of the song. The students have to write the vocabularies they got in every meeting. Furthermore, the teacher went to discuss the listening in National Examination script. Finally, the teacher ask ed the students to comprehend all items of listening section.

In observing, the teacher observed the students' respond, motivation, and comprehension towards the media given. They were noted in observation sheet during the teaching and learning in listening class.

In reflecting, the teacher analyzed the students' listening achievement through some questions of former National Examination script. It aimed to know the succesfulness of the research. 


\section{RESULTS}

The students' listening comprehension and their learning motivation that taught with song were increased significantly from preliminary, cycle 1 , and cycle 2 . Those improvement was depicted with two following explanations on a table and graphic.

\section{The Result of Students' Listening Comprehension}

The students' listening comprehension showed the improvement from the preliminary, cycle 1 , and cycle 2 . It was proved with the table of score obtained by the students from each cycle.

Table of Students' Listening Achievement

\begin{tabular}{|c|c|c|c|c|c|c|c|}
\hline \multirow{2}{*}{$\begin{array}{l}\mathbf{N} \\
\mathbf{0}\end{array}$} & \multirow{2}{*}{$\begin{array}{c}\text { Range } \\
\text { d } \\
\text { Score }\end{array}$} & \multicolumn{2}{|c|}{ Pre-liminary cycle } & \multicolumn{2}{|c|}{ Cycle 1} & \multicolumn{2}{|c|}{ Cycle 2} \\
\hline & & $\begin{array}{c}\text { Frequenc } \\
\mathbf{y}\end{array}$ & $\begin{array}{l}\text { Percentag } \\
\text { e }\end{array}$ & $\begin{array}{c}\text { Frequenc } \\
y\end{array}$ & $\begin{array}{l}\text { Percentag } \\
\text { e }\end{array}$ & $\begin{array}{c}\text { Frequenc } \\
\mathbf{y}\end{array}$ & $\begin{array}{l}\text { Percentag } \\
\text { e }\end{array}$ \\
\hline 1. & $1-5$ & 6 students & $21 \%$ & - & $0 \%$ & - & $0 \%$ \\
\hline 2. & $6-10$ & $\begin{array}{c}11 \\
\text { students }\end{array}$ & $39 \%$ & 3 students & $11 \%$ & 2 students & $7 \%$ \\
\hline 3. & $11-15$ & 8 students & $29 \%$ & $\begin{array}{c}14 \\
\text { students }\end{array}$ & $50 \%$ & 5 students & $18 \%$ \\
\hline 4. & $16-20$ & 2 students & $7 \%$ & 8 students & $29 \%$ & $\begin{array}{c}11 \\
\text { students }\end{array}$ & $39 \%$ \\
\hline 5. & $21-25$ & 1 students & $4 \%$ & 3 students & $11 \%$ & $\begin{array}{c}10 \\
\text { students }\end{array}$ & $36 \%$ \\
\hline 6. & $26-30$ & - & $0 \%$ & - & $0 \%$ & - & $0 \%$ \\
\hline & Total & $\begin{array}{c}28 \\
\text { Students }\end{array}$ & $100 \%$ & $\begin{array}{c}28 \\
\text { Students }\end{array}$ & $100 \%$ & $\begin{array}{c}28 \\
\text { Students }\end{array}$ & $100 \%$ \\
\hline
\end{tabular}

From the results on a table above, it could be known that ; In pre-liminary cycle, the students could not comprehend the listening well. About $89 \%$ of students got under the minimum score 20 and only $11 \%$ of students passed it. It indicated that the students' listening comprehension was still low.

In cycle 1, the students' listening comprehension showed the improvement. Around a half total of students reached score in range $11-15$. But, less than $75 \%$ of students were still 
under the criteria of success. It pointed that the teacher have to revise the teaching and learning and continue it to the further cycle.

In cycle 2, the students' listening comprehension was totally increased. Around $75 \%$ of students got more than 20 score. The result on cycle 2 trully fitted with the target of success in the study. They able to comprehend the content of talks in every parts ; Short Dialogue, Question and Response, Picture, and Monologue. Therefore, the teacher decided to stop the research in cycle 2 .

\section{The Result of Students' Learning Motivation}

The research also measured the students' learning motivation in the classroom. It was observed from pre-liminary, cycle 1 , and cycle 2 . The significant improvement was described on the graphic below.

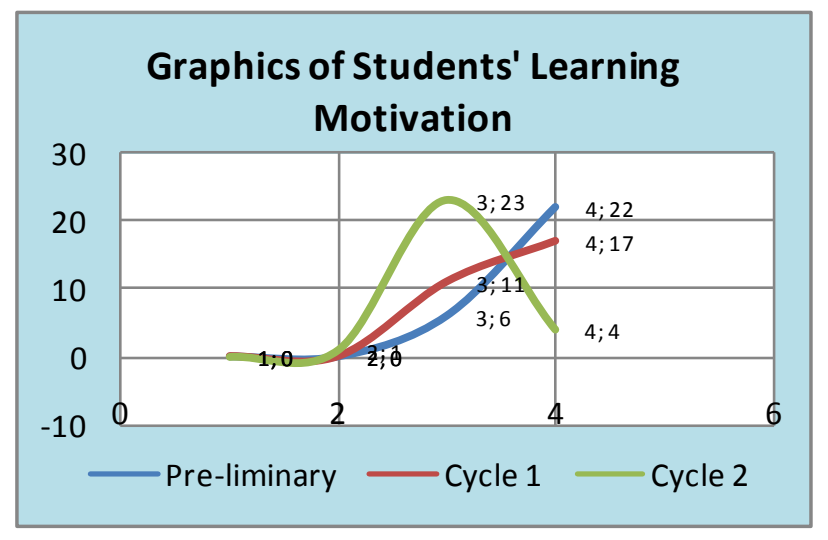

Based on the graphic above, it indicated that the students' learning motivation reached the improvement in every cycle from pre-liminary, cycle 1 , and cycle 2 . In pre-liminary, most students were not interested in following the listening class. From 4 criteria ; Excellent, Good, Enough, and Poor, the students' learning motivation was in enough and poor.

In cycle 1, the line of graphic rose higher as describing the increase of the students' learning motivation. The students seemed to be more attracted to the learning that used media of song. It was showed with their level of motivation in enough and some students were still in poor. As the listening achievement in cycle 1 was also not successful yet, so the teacher continue to cycle 2 to measure their learning motivation as well.

In cycle 2, the students' learning motivation got more improvement than previous cycle. In majority, the students' motivation was in enough level and there was a students in good level. Regarding this success, the teacher believed that cycle 2 had to be stopped. 


\section{DISCUSSION}

In this section, the teacher tries to compare the result of cycle 1 and cycle 2 with the findings of previous studies. The comparison contains the effectiveness of song in listening class and the students' listening achievement.

The result of this research showed that the students' listening comprehension was increased significantly. It could be seen from pre-liminary cycle, there was $11 \%$ of students passed the minimum score, in cycle 1 increased to be $60 \%$ of students reached the minimum score, and in cycle 2 more increased to be $75 \%$ of students got the minimum score of 20 . The students' learning motivation was also improved as their listening achievement.

Those improvement was also happened on both first and second studies. First,Sung Kim and Koo Kang (2015)resulted that English pop songs increased the students' interest andmotivation forlearning English, which were turned out to help the students get about three times morescores. Hence, using Englishpop songs for middle school students in belowaverage level is a very effective way of teaching and learningEnglish by motivating them to pay more attention to the songs and the lyrics, which led to higher scores inthe national English listening test and national English achievement test after 10 months. The students' learning interest was also proved with before and after survey, from 55,4\% of students did not attract to listening class, it became $83,7 \%$ of students said that listening is their favorite.

The second, in Arevalo (2010), the findings of his study indicated that the type of materialcan foster listening skills and engage students in discussion about cultural and social issues.Likewise, results show that practicing listening with songs can become a good way to train studentsin the development of higher levels of comprehension.

Based on the the comparison of the findings in present and previous studies, it could be indicated that songs facilitate the learning of a language in interesting and effective waysand also increase the listening comprehension especially for the students who are going to have National Examination.

\section{CONCLUSION}

From the findings showed in the research, it can be concluded that song is very helpful for increasing the students' listening comprehension and their learning motivation for facing National Examination. It was used to stimulate at the beginning of learning by listening the song, mentioning the vocabularies which have been heard on the song, and comprehending the content of song. 
Furthermore, the result of the research showed that the students' listening comprehension was increased significantly. It could be seen from pre-liminary cycle, there was $11 \%$ of students passed the minimum score, in cycle 1 increased to be $60 \%$ of students reached the minimum score, and in cycle 2 more increased to be $75 \%$ of students got the minimum score of 20. The students' learning motivation was also improved as their listening achievement.It made the teacher stop the research on cycle 2 , because the result had met the criteria of success.

\section{SUGGESTIONS}

As the result of findings, there are some suggestion for English teachers and other researchers who have similar problems. English teachers are strongly encouraged to use song to improve the students' listening ability in the class. It is very helpful when the students seem to be bored in following the class. The teacher can encourage the students to sing together while listening the real song. The class will be more interesting and effective.

For the researchers, they can adapt the result of findings and cite the teaching procedure in this research for their future research without copying-pasting. The students who are going to have National Examination are also encouraged to practice their listening abilities at home with listening song and comprehend the content of the song. The more they listen English song, the more they can increase the comprehension.It is better for them to make schedule and duration of listening the song at their own homes every day.

The last suggestion is also addressed to learning media developers for creating the media of listening to facilitate the English teachers apply the song in the class. They can devide the songs into some levels and make some various questions to test the students' listening abilities.

\section{REFERENCES}

APA (2009). Publication Manual of the American Psychological Association $\left(^{\text {th }}\right.$ Ed.).Washington, DC: American Psychological Association.

Arevalo, Edgar. (2010). The use of songs as a tool to work on listening and culture in EFL classes. Hispánica N. ${ }^{\circ}$ 15ISSN 0121-053XEnero-Junio 2010; p. 121-138 
Brown, S. (2006). Teaching Listening. Cambridge: Cambridge University Press.

Kemmis, S. and Taggart, R (1998). The Action Research Planner. Deakin : Deakin University.

Kim, Jin-Sung and Kang, Mun-Koo. (2015).The Effects of Developing English Listening Ability of Middle School Students through English Pop Songs. Asia-pacific Journal of Multimedia Services Convergent with Art, Humanities, and Sociology Vol.5, No.2 (2015), pp.175-182. http://dx.doi.org/10.14257/AJMAHS.2015.04.33.

Millington, Neil T. (2011). Using Songs Effectively to Teach English to Young Learners. ELT Journal,2(1), 134-141. http://dx.doi.org/10.5746/LEiA/11/V2/I1/A11/Millington

Murphey, T. (1992). Music and song. Oxford, England: Oxford University Press.

Purcell, J. M. (1992). Using songs to enrich the secondary class. Hispania, 75(1), 192-196. http://dx.doi.org/10.2307/344779

Richard, Jack J. (2008). Teaching Listening and Speaking From Theory to Practice. US A : Cambridge University Press. 